九州大学学術情報リポジトリ

Kyushu University Institutional Repository

\title{
Selected Chamical Properties of Alluvial Soils in Vietnam
}

Nguyen Quang Hai

Laboratory of Soil Science, Division of Soil Science and Plant Production, Department of Plant Resources, Graduate School of Bioresource and Bioenvironmental Sciences, Kyushu University

Egashira, Kazuhiko

Pham, Quang Ha

Department of Soil Environment Research, National Institute for soils and Fertilizers (NISF)

Ho Quang Duc

Department of Soil Genesis and Classification Research, NISF

https://doi.org/10.5109/4640

出版情報：九州大学大学院農学研究院紀要. 50 (1)，pp. 233-242，2005-02-01. Faculty of Agriculture, Kyushu University

バージョン :

権利関係 : 


\title{
Selected Chemical Properties of Alluvial Soils in Vietnam
}

\author{
NGUYEN Quang Hai ${ }^{1}$, Kazuhiko EGASHIRA*, PHAM Quang Ha $^{2}$ \\ and HO Quang Duc ${ }^{3}$
}

\author{
Laboratory of Soil Science, Division of Soil Science and Plant Production, \\ Department of Plant Resources, Faculty of Agriculture, \\ Kyushu University, Fukuoka 812-8581, Japan \\ (Received October 25, 2004 and accepted November 11, 2004)
}

\begin{abstract}
In the present study, 16 profiles of alluvial soils of Vietnam were collected throughout the country and analyzed for some selected chemical properties. The soil $\mathrm{pH}$ was found to be controlled by several factors such as soil forming process, parent material, landform and land management, and the organic carbon (OC) content was mainly dependent on soil forming process and land management. Within soil profile, the $\mathrm{pH}$ was a little lower at the surface horizon and was remarkably constant throughout the lower horizons in Eutric Fluvisols and Dystric Fluvisols, whereas it decreased with depth in Cambic Fluvisols and Gleyic Fluvisols. The OC content was higher at the surface and decreased irregularly with depth in case of Eutric Fluvisols and Dystric Fluvisols while increased with depth in Gleyic Fluvisols. The cation exchange capacity (CEC) and the content of exchangeable cations were controlled by sediment sources and showed the regional variations. As a result, soils were divided into three groups based on the river systems. The variability in CEC of soils in the Red River system and the other small rivers system was large, whereas it was relatively small in the Mekong River system. Average of CEC was larger for the latter than for the former. Alluvial soils distributed in the large basins of the Red River and the Mekong River systems had the high content of exchangeable cations, especially $\mathrm{Ca}^{2+}$ and $\mathrm{Mg}^{2+}$, in comparison with alluvial soils from the small drainage basins of the other rivers system.
\end{abstract}

\section{INTRODUCTION}

Vietnam has a total land area of about $331,000 \mathrm{~km}^{2}$, of which 3.5 million ha are alluvial soils distributed throughout the country, mainly in the Red River Delta (around 600 thousand ha) and the Mekong River Delta (approximately 850 thousand ha) (NISF and DSTPQ, MARD, 2002). Because of their high soil fertility, flat topography, and favorable irrigation condition, alluvial soils have been used for intensive cultivation of paddy rice and cash crops, leading to the regional or national socio-economic development (Pham et al., 2003).

Alluvial soils in Vietnam are divided into 3 units: alluvial soils of the Red River system, alluvial soils of the Mekong River system, and alluvial soils of the other rivers system. In general, alluvial soils in the Red River and Mekong River Deltas are good in terms of

1 Laboratory of Soil Science, Division of Soil Science and Plant Production, Department of Plant Resources, Graduate School of Bioresource and Bioenvironmental Sciences, Kyushu University

"Department of Soil Environment Research, National Institute for Soils and Fertilizers (NISF), Dongngac, Tuliem, Hanoi, Vietnam

3 Department of Soil Genesis and Classification Research, NISF, Dongngac, Tuliem, Hanoi, Vietnam

* Corresponding author (E-mail: kegashi@agr.kyushu-u.ac.jp) 
chemical and physical properties. Alluvial soils of the other rivers system have the lower soil fertility because of the relatively poor chemical properties (NISF and DSTPQ, MARD, 2002).

In Vietnam, $\mathrm{pH}$, organic carbon (OC) content, cation exchange capacity (CEC) and content of exchangeable cations are commonly considered the main chemical properties concerning soil quality. In the present paper, we examined these chemical properties for 16 profiles of alluvial soils collected throughout the country and clarified the factors controlling them.

\section{MATERIALS AND METHODS}

\section{Soils}

General information on 16 alluvial soil profiles collected from different agro-ecological regions and river systems is shown in Table 1. All of these soil samples were collected in the two projects: (1) Surveying and Evaluating Soil Quality to Establish Soil Reference, Database and Information; and (2) Study in Establishing the Data Guidelines on Environmental Quality of Vietnam Fluvisols. Seven out of 16 profiles belong to the Red River Delta region, of which 5 are from the Red River system (RD1 through RD5) and 2 from the Thaibinh River system (TB1 and TB2). Profiles MA1 (Ma River system) and LM1 and LM2 (Lam River system) belong to the North of Central region. Profiles TK1 (Trakhuc River system) and BA1 (Ba River system) are distributed in the Costal Area of Southern Central region. Profile DN1 from the Dongnai River system is in the East of the South region and profiles MK1 through MK3 from the Mekong River system are in the West of the South region.

All of these soils are distributed on flat plain and subjected to intensive paddy rice cultivation (annually two or three cropping of rice) except for profile DN1 which is used

Table 1. General information on alluvial soils in Vietnam.

\begin{tabular}{|c|c|c|c|c|}
\hline Profile & $\begin{array}{c}\text { Location } \\
\text { (district, province) }\end{array}$ & $\begin{array}{l}\text { Agro-ecological } \\
\text { region }\end{array}$ & River system & $\begin{array}{c}\text { Soil classification } \\
\text { (FAO/UNESCO) }\end{array}$ \\
\hline $\mathrm{RD} 1$ & Thuong Tin, Ha Tay & \multirow[t]{7}{*}{ Red River Delta } & Red River & Eutric Fluvisols \\
\hline $\mathrm{RD} 2$ & Khoai Chau, Hung Yen & & Red River & Eutric Fluvisols \\
\hline RD3 & Kien Xuong, Thai Binh & & Red River & Dystric Fluvisols \\
\hline RD4 & Vu Ban, Nam Dinh & & Red River & Gleyic Fluvisols \\
\hline RD5 & Duy Tien, Ha Nam & & Red River & Gleyic Fluvisols \\
\hline TB1 & Quynh Phu, Thai Binh & & Thaibinh River & Dystric Fluvisols \\
\hline TB2 & Cam Binh, Hai Duong & & Thaibinh River & Cambic Fluvisols \\
\hline MA1 & Yen Dinh, Thanh Hoa & \multirow[t]{3}{*}{ North of Central } & Ma River & Dystric Fluvisols \\
\hline LM1 & Hung Nguyen, Nghe An & & Lam River & Dystric Fluvisols \\
\hline LM2 & Duc Tho, Ha Tinh & & Lam River & Cambic Fluvisols \\
\hline TK1 & Tu Nghia, Quang Ngai & \multirow{2}{*}{$\begin{array}{l}\text { Costal Area of } \\
\text { Southern Central }\end{array}$} & Trakhuc River & Cambic Fluvisols \\
\hline $\mathrm{BA} 1$ & Tuy Hoa, Phu Yen & & Ba River & Dystric Fluvisols \\
\hline DN1 & Vinh Cuu, Dong Nai & East of the South & Dongnai River & Dystric Fluvisols \\
\hline MK1 & Cao Lanh, Dong Thap & \multirow[t]{3}{*}{ West of the South } & Mekong River & Eutric Fluvisols \\
\hline MK2 & Chau Thanh, Long An & & Mekong River & Dystric Fluvisols \\
\hline MK3 & Thot Not, Can Tho & & Mekong River & Gleyic Fluvisols \\
\hline
\end{tabular}


for cultivation of fruit trees. According to the FAO/UNESCO soil classification system, 16 profiles are divided into 4 soil units: Eutric Fluvisols, Dystric Fluvisols, Gleyic Fluvisols, and Cambic Fluvisols. Among them, Eutric Fluvisols are by far the youngest alluvial soils and normally distributed adjacent to the river and show distinct stratification while the others are considered older soils and distributed in basin areas away from the river. Gleyic Fluvisols develop on the area where soils are completely saturated with groundwater at least for a period of a year, that allows occurrence of the reducing condition, and show the gleyic property. Cambic Fluvisols or altered alluvial soils are located at higher terrace and have a subsurface horizon showing evidence of advanced alteration, like a color of strong chroma and red hue, relative to the underlying horizons.

Soil samples were taken vertically with profile depth based on the genetic horizons, air-dried and gently ground to pass through a 1-mm sieve, and subjected to chemical analyses. Chemical analyses were carried out at the National Institute for Soils and Fertilizers, Hanoi, Vietnam.

\section{Procedures for chemical analyses}

The $\mathrm{pH}\left(\mathrm{H}_{2} \mathrm{O}\right)$ was measured in the suspension having a soil/water ratio of $1 / 2.5$ by a $\mathrm{pH}$ meter. The organic carbon (OC) content was determined by the Walkley-Black method. This involves a wet combustion of organic matter with a mixed solution of potassium dichromate and sulphuric acid. After reaction the residual dichromate is titrated against the ferrous sulphate solution with barium diphenylamine sulphonate as an indicator.

In the determination of cation exchange capacity (CEC), the sample was repeatedly percolated with the sodium acetate solution. Excess salt was removed and then adsorbed $\mathrm{Na}$ was exchanged with the ammonium acetate solution by percolation. Sodium in the percolated solution was measured for CEC. For the determination of the contents of exchangeable cations, the sample was repeatedly extracted with $1 \mathrm{M}$ ammonium acetate $(\mathrm{pH}=7.0)$. Calcium, $\mathrm{Mg}, \mathrm{K}$, and $\mathrm{Na}$ in the extracted solution were measured by an atomic absorption spectrophotometer.

\section{RESULTS AND DISCUSSION}

Selected chemical properties including $\mathrm{pH}$, OC content, $\mathrm{CEC}$ and contents of exchangeable cations of alluvial soils are shown in Table 2. The data were taken in triplicate measurements and processed statistically.

\section{pH}

The $\mathrm{pH}$ of alluvial soils was controlled by soil forming process, parent material, landform, and land management. As shown in Table 2, the $\mathrm{pH}$ was high in Eutric Fluvisols (profiles RD1, RD2 and MK1) with values mostly over 6.0. Profile RD1 was in the slightly alkaline condition with $\mathrm{pH}$ values ranging from 8.4 to 8.7 , suggesting originating from calcareous sediments (Nguyen and Egashira, 2000). In profiles MA1 and LM1 (Dystric Fluvisols), $\mathrm{pH}$ values were over 7.0 in most horizons. This can be attributed to origin of weathered materials of basic rocks transported from surrounding areas, namely limestone for profile MA1 and basalt for profile LM1. In other profiles of Eutric Fluvisols and 
Table 2. Selected chemical properties of alluvial soils in Vietnam.

\begin{tabular}{|c|c|c|c|c|c|c|c|c|}
\hline \multirow{2}{*}{ Profile } & \multirow{2}{*}{$\begin{array}{l}\text { Depth } \\
(\mathrm{cm})\end{array}$} & \multirow{2}{*}{$\begin{array}{c}\mathrm{pH} \\
\left(\mathrm{H}_{2} \mathrm{O}\right)\end{array}$} & \multirow{2}{*}{$\begin{array}{l}\text { OC } \\
(\%)\end{array}$} & \multirow{2}{*}{$\begin{array}{c}\mathrm{CEC} \\
\left(\mathrm{cmol}_{\mathrm{c}} / \mathrm{kg}\right)\end{array}$} & \multicolumn{4}{|c|}{ Exchangeable cations $\left(\mathrm{cmol}_{\mathrm{C}} / \mathrm{kg}\right)$} \\
\hline & & & & & $\mathrm{Ca}$ & $\mathrm{Mg}$ & $\mathrm{K}$ & $\mathrm{Na}$ \\
\hline \multirow[t]{3}{*}{ RD1 } & $20-40$ & 8.4 & 1.31 & 11.48 & 8.55 & 0.43 & 0.13 & 0.26 \\
\hline & $56-76$ & 8.7 & 1.18 & 10.57 & 6.65 & 0.41 & 0.12 & 0.27 \\
\hline & $135-147$ & 8.7 & 0.41 & 11.37 & 7.57 & 0.51 & 0.14 & 0.31 \\
\hline \multirow[t]{7}{*}{ RD2 } & $0-15$ & 5.1 & 0.78 & 13.40 & 4.00 & 3.75 & 0.19 & 0.28 \\
\hline & $15-25$ & 6.3 & 0.59 & 9.20 & 3.75 & 3.75 & 0.19 & 0.15 \\
\hline & $25-40$ & 6.5 & 0.20 & 5.90 & 2.75 & 2.50 & 0.13 & 0.11 \\
\hline & $40-70$ & 6.5 & 0.39 & 8.50 & 3.00 & 4.00 & 0.13 & 0.09 \\
\hline & $70-85$ & 6.6 & 0.37 & 9.00 & 3.00 & 4.00 & 0.13 & 0.04 \\
\hline & $85-95$ & 6.6 & 0.39 & 10.40 & 3.50 & 5.00 & 0.13 & 0.05 \\
\hline & $95-110$ & 5.8 & 0.59 & 7.70 & 2.75 & 2.25 & 0.13 & 0.02 \\
\hline RD3 & $0-15$ & 4.8 & 1.07 & 10.69 & 5.96 & 4.11 & 0.18 & 0.15 \\
\hline \multirow[t]{4}{*}{$\mathrm{RD} 4$} & $0-20$ & 5.1 & 1.28 & 12.58 & 4.19 & 3.17 & 0.18 & 0.32 \\
\hline & $30-50$ & 3.5 & 1.28 & 11.21 & 4.49 & 1.83 & 0.09 & 0.29 \\
\hline & $65-80$ & 2.8 & 1.77 & 13.98 & 3.40 & 3.36 & 0.06 & 0.27 \\
\hline & $90-110$ & 3.3 & 1.78 & 14.66 & 4.55 & 3.96 & 0.06 & 0.15 \\
\hline RD5 & $0-20$ & 5.5 & 1.07 & 8.99 & 7.36 & 2.86 & 0.26 & 0.21 \\
\hline TB1 & $0-20$ & 4.1 & 1.67 & 16.14 & 4.28 & 2.89 & 0.05 & 0.30 \\
\hline \multirow[t]{4}{*}{ TB2 } & $0-15$ & 5.4 & 1.20 & 8.26 & 4.43 & 0.47 & 0.12 & 0.36 \\
\hline & $15-23$ & 5.2 & 1.00 & 8.56 & 5.51 & 1.29 & 0.15 & 0.43 \\
\hline & $23-58$ & 4.9 & 0.90 & 10.88 & 1.15 & 0.47 & 0.24 & 0.90 \\
\hline & $58-100$ & 4.7 & 0.87 & 9.26 & 1.14 & 0.49 & 0.26 & 0.95 \\
\hline \multirow[t]{5}{*}{ MAl } & $0-10$ & 6.2 & 1.15 & 17.40 & 2.83 & 0.57 & 0.08 & 0.09 \\
\hline & $10-30$ & 7.0 & 0.61 & 10.56 & 4.82 & 1.40 & 0.08 & 0.17 \\
\hline & $30-70$ & 7.7 & 0.38 & 15.60 & 4.19 & 2.03 & 0.10 & 0.17 \\
\hline & $70-100$ & 7.6 & 0.39 & 14.60 & 5.33 & 1.19 & 0.13 & 0.23 \\
\hline & $100-130$ & 7.6 & 0.41 & 17.32 & 3.78 & 1.22 & 0.08 & 0.17 \\
\hline \multirow[t]{4}{*}{ LM1 } & $0-28$ & 5.6 & 1.93 & 6.40 & 2.32 & 0.63 & 0.26 & 0.11 \\
\hline & $28-50$ & 7.9 & 0.22 & 6.28 & 3.95 & 1.76 & 0.10 & 0.11 \\
\hline & $50-80$ & 7.5 & 0.38 & 7.76 & 4.22 & 2.90 & 0.10 & 0.20 \\
\hline & $80-105$ & 7.6 & 0.26 & 10.82 & 5.09 & 1.95 & 0.05 & 0.11 \\
\hline LM2 & $0-12$ & 4.7 & 1.90 & 10.98 & 3.00 & 1.71 & 0.08 & 0.20 \\
\hline TK1 & $0-15$ & 5.3 & 3.39 & 7.44 & 2.61 & 2.04 & 0.23 & 0.13 \\
\hline \multirow[t]{5}{*}{$\mathrm{BAl}$} & $0-15$ & 5.8 & 1.00 & 10.00 & 3.40 & 1.72 & 0.23 & 0.21 \\
\hline & $15-30$ & 5.3 & 0.58 & 14.48 & 3.04 & 1.70 & 0.05 & 0.10 \\
\hline & $30-50$ & 5.8 & 0.90 & 15.36 & 4.81 & 2.70 & 0.08 & 0.22 \\
\hline & $50-75$ & 6.0 & 0.87 & 13.32 & 3.60 & 2.40 & 0.08 & 0.23 \\
\hline & $75-110$ & 6.1 & 0.58 & 14.52 & 3.70 & 2.62 & 0.08 & 0.40 \\
\hline \multirow[t]{4}{*}{ DN1 } & $0-10$ & 6.3 & 1.21 & 14.08 & 3.76 & 1.41 & 0.41 & 0.05 \\
\hline & $10-20$ & 6.1 & 1.19 & 11.92 & 3.72 & 1.74 & 0.31 & 0.04 \\
\hline & $20-70$ & 6.3 & 0.48 & 11.28 & 2.25 & 2.19 & 0.10 & 0.09 \\
\hline & $70-120$ & 6.0 & 0.40 & 12.40 & 1.91 & 2.74 & 0.08 & 0.08 \\
\hline \multirow[t]{5}{*}{ MK1 } & $0-10$ & 4.5 & 1.93 & 13.04 & 6.05 & 1.75 & 0.12 & 0.27 \\
\hline & $10-20$ & 6.2 & 0.77 & 14.16 & 9.64 & 3.31 & 0.12 & 0.25 \\
\hline & $20-55$ & 6.6 & 0.52 & 13.20 & 8.45 & 3.27 & 0.12 & 0.21 \\
\hline & $55-95$ & 6.5 & 0.45 & 16.80 & 7.57 & 3.08 & 0.10 & 0.19 \\
\hline & $95-130$ & 6.5 & 0.23 & 13.76 & 8.02 & 2.34 & 0.08 & 0.14 \\
\hline MK2 & $0-10$ & 4.4 & 3.46 & 16.49 & 4.31 & 11.32 & 0.25 & 0.13 \\
\hline \multirow[t]{5}{*}{ MK3 } & $0-15$ & 4.8 & 3.04 & 12.00 & 5.63 & 4.10 & 0.12 & 0.54 \\
\hline & $15-30$ & 4.3 & 3.11 & 14.24 & 2.17 & 3.34 & 0.07 & 0.49 \\
\hline & $30-60$ & 4.2 & 2.73 & 10.88 & 1.84 & 3.33 & 0.12 & 0.20 \\
\hline & $60-90$ & 4.0 & 3.15 & 15.84 & 2.26 & 4.85 & 0.23 & 0.39 \\
\hline & $90-130$ & 4.1 & 0.68 & 14.48 & 2.49 & 6.10 & 0.43 & 0.51 \\
\hline
\end{tabular}


Dystric Fluvisols, the $\mathrm{pH}$ normally ranged from 5.5 to 6.5 . The $\mathrm{pH}$ was a little lower for Cambic Fluvisols (profiles TB2, LM2 and TK1), and lowest for Gleyic Fluvisols (profiles RD4 and MK3) with values around or below 4.0.

The vertical distribution of $\mathrm{pH}$ in a profile is shown in Fig. 1 for profiles RD2, LM1, TB2, and RD4 as representatives of Eutric, Dystric, Cambic, and Gleyic Fluvisols, respectively. Alluvial soils used in the present study mostly belong to Eutric Fluvisols and Dystric Fluvisols in which the $\mathrm{pH}$ was a little lower at the surface horizon and remarkably constant throughout the lower horizons. The lower $\mathrm{pH}$ at the surface may be consequence of application of chemical fertilizers such as urea and super-phosphate at a very high level due to intensive paddy rice cultivation. Transformation of chemical fertilizers releases materials that make soil acidic. For example, transformation of 1 mole ammonium ion into 1 mole nitrate ion will release 2 moles of $\mathrm{H}^{+}$(Pham et al., 2003).

Formation of cambic horizon in Cambic Fluvisols produces subsurface horizons rich in iron compounds. Oxidation of ferrous compounds to ferric compounds in the lower horizons occurs when they are exposed naturally or artificially to the oxidized condition, and leads to lowering of $\mathrm{pH}$ of them (Nguyen and Tran, 1978). Air-drying of soil samples as a pretreatment is considered a reason for the $\mathrm{pH}$ around or below 4.0 in the subsurface horizons of Gleyic Fluvisols. The subsurface horizons of Gleyic Fluvisols in the present study probably have the sulfidic nature, and pyrite as a sulfidic compound was oxidized by air-drying in the laboratory. According to Driessen and Dudal (1989), pyritic sediments are common in the depressions of the Mekong Delta where extensive areas of Thionic Fluvisols (acid sulfate soils) are distributed. The depressions are also the areas where Gleyic Fluvisols are formed and their associated distribution would result in transportation of pyrite from acid sulfate soils to Gleyic Fluvisols.

In addition, the blue-gray coloured mottles in the gleyic horizon have been ascribed
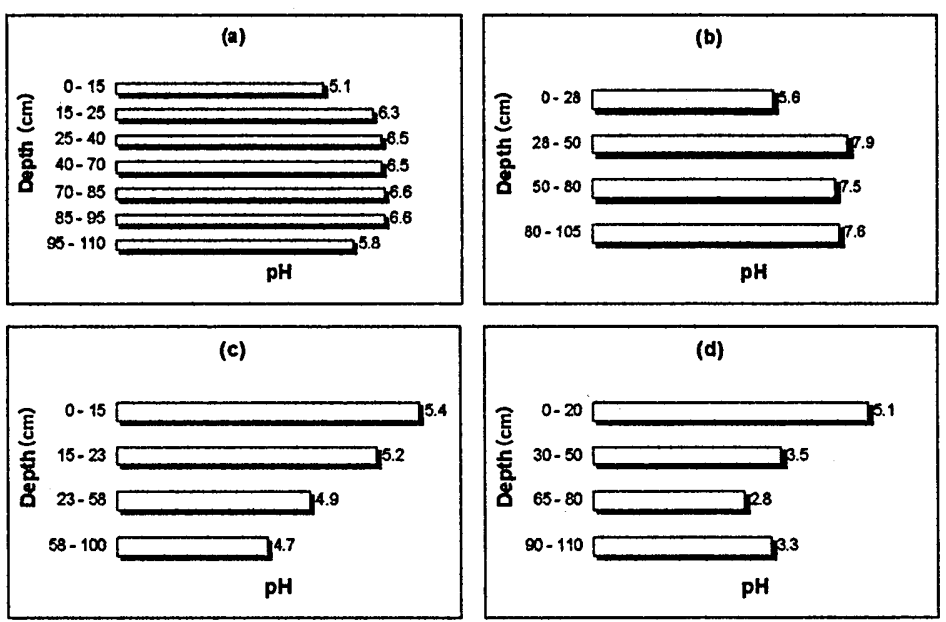

Fig. 1. The vertical distribution of $\mathrm{pH}$ in a profile for profiles (a) RD2, (b) LM1, (c) TB2, and (d) RD4 as representatives of Eutric, Dystric, Cambic, and Gleyic Fluvisols, respectively. 
to the presence of vivianite (ferrous phosphate) and ferrous sulphide (FeS) (Ross, 1989); grayish/bluish colours in the inside of the peas or in the deeper soil horizons indicate that iron ( $\mathrm{Fe}$ ) and manganese $(\mathrm{Mn})$ oxides/hydroxides were transformed into insoluble Fe/Mn(II) compounds (ISSS/ISRIC/FAO, 1998). Oxidation of these compounds during air-drying of soil samples would result in the low $\mathrm{pH}$ values in Gleyic Fluvisols, especially for those in the Red River system where Gleyic Fluvisols are distributed apart from acid sulfate soils.

\section{Organic carbon content}

The OC contents of alluvial soils are given in Table 2 , and the vertical distribution of the OC content in a profile are illustrated in Fig. 2 for each representative profile of the four soil units. The level and profile distribution of the OC content of alluvial soils were depending on soil forming process and land management. Irregular decrease of the OC content with depth reflects stratification of the sediments which is the nature of alluvial soils (ISSS/ISRIC/FAO, 1998).

In the present study, most profiles were found to keep still the nature of alluvial soils, especially in Eutric Fluvisols and Dystric Fluvisols, because in both soil units it was observed that the OC content was higher at the surface horizon (1-2\%) and decreased irregularly with depth to the level of $0.2-0.4 \%$ (Fig. 2). The higher OC content at the surface would be related to application of a high amount of organic amendments (12-13 ton/ha/year in average) as compost or crop residues.

In Cambic Fluvisols which is a soil unit that has been altered in advance, the OC content decreased with depth but the value observed in the subsurface horizons was still high ( $0.8 \%$ or more). According to Ross (1989), the lower $\mathrm{pH}$ results in a less varied decomposer population with slower rates of decomposition of organic matter. The
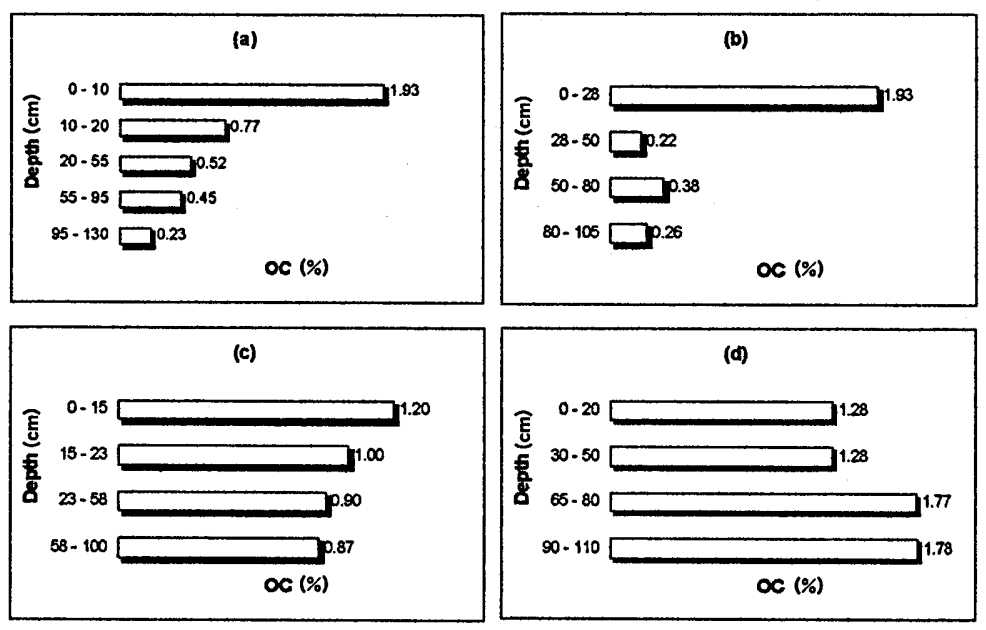

Fig. 2. The vertical distribution of the organic carbon content in a profile for profiles (a) MK1, (b) LM1, (c) TB2, and (d) RD4 as representatives of Eutric, Dystric, Cambic, and Gleyic Fluvisols, respectively. 
decrease of $\mathrm{pH}$ with depth in Cambic Fluvisols would cause $\mathrm{OC}$ accumulated at a high rate in the subsurface horizons in comparison with that of Eutric Fluvisols and Dystric Fluvisols.

Research on accumulation of organic matter in soils under the anaerobic condition (Kilham and Alexander, 1984) has pointed out following items as main reasons for the less rapid decay of carbonaceous compounds in waterlogged soils: (1) lack of electron acceptors for respiration processes; (2) production of end products such as hydrogen sulphide and ethylene which are toxic to soil microorganisms; and (3) presence of higher concentration of fatty acids such as acetic and butyric acids which inhibit microbial activity, particularly at low $\mathrm{pH}$. These reasons may also be applicable to the vertical distribution of the OC content of Gleyic Fluvisols. Namely, the OC content of profiles $\mathrm{RD} 4$ and MK3 was high even in the subsurface horizons and more than $1 \%$ throughout the profile for profile RD4 and around 3\% for profile MK3.

\section{Cation exchange capacity}

The characteristics of alluvial soils are closely related to geology of the riverhead from which sediments are transported. Different river systems have different sediment sources which affect chemical properties, especially CEC and contents of exchangeable cations, of alluvial soils in the river basin. Based on the sources of sediments, alluvial soils in Vietnam are divided into 3 groups, according to the Vietnamese traditional soil classification system. All profiles originating from the Red River sediments are combined into one group, named alluvial soils of the Red River system and representing the biggest river basin in the North. Profiles MK1, MK2 and MK3 are combined into one group, representing the biggest river basin in the South, which is named alluvial soils of the Mekong River system. The similarity of these two groups is distribution in a very large basin and in the very far distance from the sediment sources. Profiles originating from the other rivers sediments, distributed from the North of Central to the East of the South regions, are combined into one group and named alluvial soils of the other rivers system. The drainage basins of the third group are individually small, surrounded by upland regions, and adjacent to the sediment sources. Cation exchange capacity and the contents of exchangeable cations of alluvial soils in the present study were differentiated depending on these three groups rather than on soil units.

As shown in Table 3, CEC of all three groups was generally low, with values below $18 \mathrm{cmol}_{\mathrm{c}} / \mathrm{kg}$. The averaged CEC of alluvial soils was highest for the Mekong River system $\left(14.08 \mathrm{cmol}_{\mathrm{c}} / \mathrm{kg}\right)$, then for the other rivers system $\left(11.82 \mathrm{cmol}_{\mathrm{c}} / \mathrm{kg}\right)$, and lowest for the Red River system $\left(10.71 \mathrm{cmol}_{\mathrm{C}} / \mathrm{kg}\right)$. The CEC varied more or less remarkably within a profile (Table 2), probably reflecting stratification of sediments in alluvial soils. For example, the

Table 3. Cation exchange capacity of the three groups of alluvial soils in Vietnam.

\begin{tabular}{lrrrr}
\hline \multicolumn{1}{c}{ Group } & $n$ & Min. & Max. & Mean \\
\hline Alluvial soils of the Red River system & 16 & 5.90 & 14.66 & 10.71 \\
Alluvial soils of the Mekong River system & 11 & 12.00 & 16.80 & 14.08 \\
Alluvial soils of the other rivers system & 25 & 6.28 & 17.40 & 11.82 \\
\hline
\end{tabular}


CEC varied from 11.21 to $14.66 \mathrm{cmol}_{\mathrm{C}} / \mathrm{kg}$ in profile $\mathrm{RD} 4$, from 10.00 to $15.36 \mathrm{cmol}_{\mathrm{C}} / \mathrm{kg}$ in profile $\mathrm{BA} 1$, and from 13.04 to $16.80 \mathrm{cmol}_{\mathrm{C}} / \mathrm{kg}$ in profile MK1. The CEC considerably varied within alluvial soils of each group of the Red River and the other rivers systems: variation from 5.90 to $14.66 \mathrm{cmol}_{\mathrm{c}} / \mathrm{kg}$ for the former and from 6.28 to $17.40 \mathrm{cmol}_{\mathrm{C}} / \mathrm{kg}$ for the latter. The variability in CEC within alluvial soils of the Mekong River system was relatively small, with a range between 12.00 and $16.80 \mathrm{cmol}_{\mathrm{C}} / \mathrm{kg}$.

In the Red River system, dike systems have been constructed to protect agricultural land from heavy floods in rainy season. It resulted in profound changes of alluvial soils inside the dike system to form different soil types with a large variability in chemical properties such as CEC mentioned above. The characteristics of alluvial soils of the other rivers system depend on the sediments of individual river so that the difference in CEC was large between different river systems. For example, the CEC of alluvial soils of the Lam River was 6.28 to $10.82 \mathrm{cmol}_{\mathrm{c}} / \mathrm{kg}$ and that of the Ma river was 10.56 to $17.40 \mathrm{cmol}_{\mathrm{c}} / \mathrm{kg}$. Water regime or hydrology of the Mekong River is equable and there is no dike in this basin. A large amount of alluvium flows along an interlacing net with $3,000 \mathrm{~km}$ long of streams and channels and then spreads evenly on the basin. This not only supports nutrition for alluvial soils annually but also makes the basin flat in comparison with the Red River and the other rivers basins (Pham et al., 2003). That might explain why the variability in CEC of soils of the Mekong River system was so small.

\section{Exchangeable cations contents}

The amount and composition of exchangeable cations are considered a decisive factor of the CEC "quality". The higher amount of basic cations is related to crop nutrients such as $\mathrm{Ca}^{2+}, \mathrm{Mg}^{2+}$ and $\mathrm{K}^{+}$, leading to the higher CEC "quality" (Dao, 1987). Therefore, in the present paper exchangeable cations were analyzed and are shown as percentage they occupy in CEC in Fig. 3. In this figure, the percentage is a averaged value for soils of the respective river systems, and other cations mean $\mathrm{H}^{+}, \mathrm{Fe}^{3+}$ and $\mathrm{Al}^{3+}$, other than $\mathrm{Ca}^{2+}, \mathrm{Mg}^{2+}$, $\mathrm{K}^{+}$and $\mathrm{Na}^{+}$.

In all soil samples $\mathrm{K}^{+}$and $\mathrm{Na}^{+}$occupied a small percentage, only about 1 and $2 \%$, respectively, in CEC. In alluvial soils of the Red River system, occupation of $\mathrm{Ca}^{2+}$ in CEC was $44.5 \%$ and high compared with that of alluvial soils of the Mekong River system (37.7\%) and of the other rivers system (30.1\%). Occupation of $\mathrm{Mg}^{2+}$ in CEC in alluvial soils of the Red River and Mekong River systems was almost the same with each other and was $27.1 \%$ and $30.2 \%$, respectively. Other cations of both river systems showed the comparable possession in $\mathrm{CEC}$ with $\mathrm{Mg}^{2+}$. In alluvial soils of the other rivers system, in contrast, $\mathrm{Mg}^{2+}$ occupied a small percentage in CEC with a value of only $14.3 \%$, whereas other cations showed a large percentage and occupied almost half of CEC.

In the present study, basic cations of alluvial soils ranged in the order of $\mathrm{Ca}^{2+}>\mathrm{Mg}^{2+}$ $>>\mathrm{Na}^{+}>\mathrm{K}^{+}$. This order was in agreement with those reported for alluvial soils in Vietnam by Nguyen and Tran (1978) and Pham et al. (2003). Occurrence of $\mathrm{Ca}^{2+}$ and $\mathrm{Mg}^{2+}$ at a high ratio and balanced existence with other cations in alluvial soils of the Red River and Mekong River systems indicate that these soils have a good CEC "quality". It makes them different from alluvial soils of the other rivers system in which an unbalanced ratio between exchangeable cations was observed. 


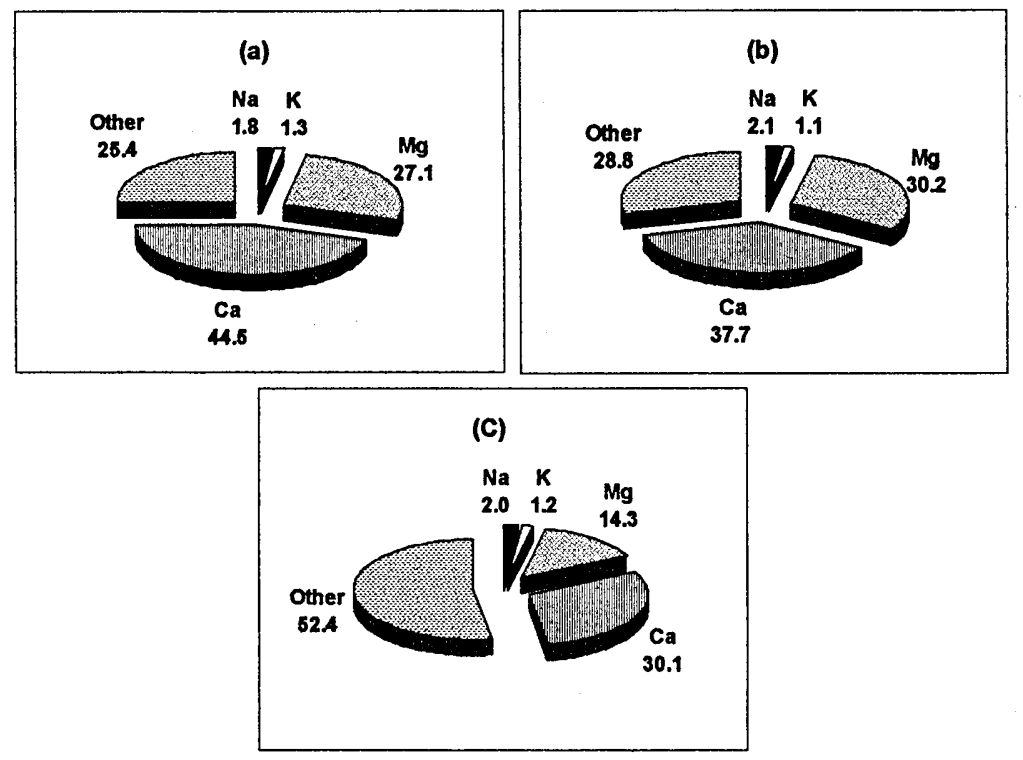

Fig. 3. Percentage of exchangeable cations occupying in CEC of alluvial soils in Vietnam: (a) alluvial soils of the Red River system; (b) alluvial soils of the Mekong River system; and (c) alluvial soils of the other rivers system.

\section{CONCLUSIONS}

The variability in $\mathrm{pH}$ and the $\mathrm{OC}$ content of alluvial soils in Vietnam was not dependent on the river system but on soil forming process, parent material, and regulations concerning cultivation of land. Eutric Fluvisols, so-called "young" alluvial soils, and alluvial soils originating from weathered materials of basic magmatic rocks were neutral in soil reaction, while Gleyic Fluvisols, "older" soils under waterlogged conditions, were strongly acidic and had the high OC content.

Cation exchange capacity and the contents of exchangeable cations were controlled by the river systems or sediment sources. Average of CEC was higher for alluvial soils of the Mekong River system, followed by the other rivers system and the Red River system. However, the variability in CEC was large among soils of the individual river system, especially in the Red River system and the other rivers system. The averaged percentage of exchangeable cations occupying in CEC varied with the river systems. Alluvial soils distributed in the large basin of the Red River and Mekong River systems had high basic exchangeable cations especially $\mathrm{Ca}^{2+}$ and $\mathrm{Mg}^{2+}$, in comparison with alluvial soils from the small drainage basin of the other rivers system.

\section{ACKNOWLEDGEMENTS}

The authors gratefully acknowledge the managers of the projects: Surveying and 
Evaluating Soil Quality to Establish Soil Reference, Database and Information in Vietnam and Study in Establishing the Data Guidelines on Environmental Quality of Vietnam Fluvisols for providing soil samples and related documents. Authors wish to thank Mr. Nguyen Van Ty and other staffs of the Department of Soil Genesis and Classification Research and staffs of the Department of Soil Environment Research, National Institute for Soils and Fertilizers, for their assistance in collecting and analyzing soil samples.

\section{REFERENCES}

Dao Chau Thu 1987 Clay Minerals and their Relation to Some Chemical Properties of Major Soils of Vietnam. Ph. D. Thesis, Hanoi Agricultural University, Hanoi, Vietnam (in Vietnamese)

Driessen P. M. and R. Dudal 1989 Lecture Notes on the Geography, Formation, Properties, and Use of Major Soils of the World. Agricultural University Wageningen-Katholieke Universiteit Leuven, Wageningen and Leuven

ISSS/ISRIC/FAO 1998 World Reference Base for Soil Resources. World soil resources reports No. 84, Rome

Kilham, O. W. and M. Alexander 1984 A basic for organic matter accumulation in soils under anaerobiosis. Soil Science, 137: 419-427

National Institute for Soils and Fertilizers (NISF) and Department of Science, Technology and Product Quality (DSTPQ), Ministry of Agriculture and Rural Development (MARD) 2002 The Basic Information of Main Soil Units of Vietnam. Thegioi Publishers, Hanoi, Vietnam

Nguyen Huu Thanh and K. Egashira 2000 Clay mineralogical composition of some Fluvisols in Vietnam. Clay Science, 11: 205-217

Nguyen Vi and Tran Khai 1978 Soil Chemistry in North of Vietnam. Technical and Scientific Public House, Hanoi, Vietnam (in Vietnamese)

Pham Quang Ha et al. 2003 Study in Establishing the Data Guidelines on Environmental Quality of Vietnam Fluvisols. Final Report, Ministry of Agriculture and Rural Development, Hanoi, Vietnam (in Vietnamese)

Ross, S. 1989 Soil Processes, a Systematic Approach. Routledge, London and New York 